were seen in the two patients receiving approximately $1,000 \mu \mathrm{g}$. of anti-D in the form of gammaglobulin intramuscularly.

The evidence suggests that $\mathrm{Rh}$ immunization by quite large transplacental haemorrhage can be safely prevented by giving anti-D gammaglobulin. A cautious approach to the use of this method in dealing with $\mathrm{Rh}$-incompatible transfusions in women before or during the child-bearing period seems justified.

We would like to thank Professor J. A. Stallworthy, Mr. C. H. de Boer, Mr. S. E. Riterband, and Dr. M. M. Pickles for permission to publish details of cases under their care. Dr. J. Darnborough carried out the serological investigations in Case 4 and Mr. W. T. A. Donohoe those in Case 1. We are indebted to Professor C. A. Clarke for his encouragement and advice in the preparation of this report. The gammaglobulin preparation of anti-D was provided by $\mathrm{Dr}$. D. Lehane in co-operation with $\mathrm{Dr}$.
W. d'A. Maycock and Mr. L. Vallet, of the Lister Institute for Preventive Medicine.

\section{REFERENCES}

Brit. med. F., 1966, 2, 907.

Clarke, C. A. (1967). Brit. med. 7., 4, 7.

Clarke, al. (1963). Ibid., 1, 979 .

Finn, R., Lehane, D., McConnell, R. B., Sheppard, P. M., and Woodrow, J. C. (1966). Ibid., 1, 213.

Finn, R., et al. (1961). Ibid., 1, 1486.

Freda, V. J., Gorman, J. G., and Pollack, W. (1964). Transfusion (Philad.), 4, 26.

Jandl, J. H., Jones, A. R., and Castle, W. B. (1957). J. clin. Invest., 36, 1428.

Kleihauer, E, and Betke, K. (1960). Internist (Berl.), 1, 292.

Mollison, P. L. (1967). Blood Transfusion in Clinical Medicine, 4th ed. Oxford.

Vogel, P., Rosenthal, N., and Levine, P. (1943). Amer. F. clin. Path.,

Woodrow, J. C. et al. (1965). Brit. med. F., 1, 279

\title{
Failure of a Relatively Small Dose of Passively Administered Anti-Rh to Suppress Primary Immunization by a Relatively Large Dose of Rh-positive Red Cells
}

\author{
N. C. HUGHES-JONES,* D.M., Ph.D. ; P. L. MOLliSON,* M.D., F.R.C.P., F.C.PATH.
}

Brit. med. F., 1968, 1, 150-151

Passively administered anti-Rh has been extraordinarily successful in suppressing primary immunization which would otherwise occur in certain $\mathrm{Rh}$-negative women after pregnancy. However, the amount of foetal red cells found in a mother's circulation after delivery is less than $1.5 \mathrm{ml}$. in $98 \%$ of cases (Clarke et al., 1966), and so far there is little experience of trying to suppress primary immunization when much larger amounts are involved, either as a result of transplacental haemorrhage or of inadvertent transfusion of $\mathrm{Rh}$-positive blood.

We here report two cases in which $\mathrm{Rh}$-negative patients received relatively large amounts of $\mathrm{Rh}$-positive red cells-in one case by transplacental haemorrhage and in the other by blood transfusion-and in which relatively small amounts of passively administered anti-Rh failed to prevent primary immunization.

\section{Case 1}

The patient. aged 26, gave birth to her first infant on 17 May 1967 ; she had not been pregnant before nor had she received a blood transfusion. The infant was very pale and appeared moribund; six hours after birth it was found to have a haemoglobin concentration of $6.3 \mathrm{~g} . / 100 \mathrm{ml}$. The mother was group $\mathrm{B} \mathrm{Rh}$ negative and the infant group B Rh-positive; the mother's serum did not contain anti-Rh and the infant's direct antiglobulin test was negative. A transplacental haemorrhage was suspected, and examination of the mother's blood by the acid-elution method showed numerous foetal red cells; from counts made in this laboratory it was estimated that approximately 1 in 36 of the red cells stained darkly. If it is assumed that the mother's red cell volume was $1,500 \mathrm{ml}$. and that the acid-elution method detects about $70 \%$ of the true number of foetal red cells present (unpublished observations) the volume of foetal red cells in the mother's circulation was approximately $60 \mathrm{ml}$.

The infant was given a blood transfusion and made a satisfactory recovery.

At about 60 hours after birth the mother was given an intramuscular injection of gammaglobulin (batch " $\mathrm{A}$ ") estimated to

- M.R.C. Experimental Haematology Research Unit, St. Mary's Hospital Medical School, London W.2. contain a total of $500 \mu \mathrm{g}$. of IgG anti-D ; the preparation contained no detectable agglutinating (IgM) anti-D. Estimates of the proportion of foetal cells present in the mother's blood were made at $2,3,6$, and 13 days after the injection of anti-D; the results are shown in Fig. 1. Half the cells disappeared in four to five days and all had gone by 13 days. Anti-D could be detected in the patient's plasma (indirect antiglobulin test) 48 hours after the injection, and it was still just detectable 20 days after the injection. A sample of serum taken from the mother seven weeks after the birth of the infant showed that anti-Rh was present to a titre of 2 ; five weeks later the titre was 16, and five weeks after this (four months after the birth of the infant) it was 32 .

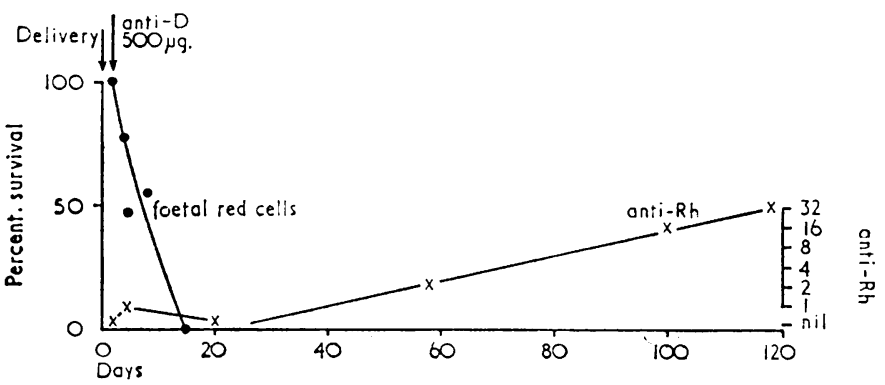

FIG. 1.-Case 1. Survival of foetal red cells in the mother's circulation and changes in the maternal anti- $\mathrm{Rh}$ titre.

\section{Case 2}

The patient, aged 21, had an abortion on 30 June 1967 . She was admitted to hospital next day because of considerable bleeding, and was transfused with two units of group $\mathrm{O} \mathrm{Rh}$-positive blood (containing a total of approximately $400 \mathrm{ml}$. of red cells) between the evening of 1 July and the morning of 2 July. It was then discovered that the patient was group $\mathrm{O} \mathrm{Rh}$-negative, and she was referred to us for treatment. On the evening of 3 July, 48 hours after the beginning of the blood transfusion, gammaglobulin (batch "B") containing $1,000 \mu \mathrm{g}$. of IgG anti-D was given intramuscularly; the preparation contained no agglutinating anti-D. Approximate estimates of the number of red cells present were made by incubating samples of the patient's blood with a potent anti-D, 
and then, after washing, incubating the cells with an antiglobulin serum. The proportion of $\mathrm{Rh}$-positive red cells present was estimated by comparison with known mixtures. As Fig. 2 shows, the Rh-positive cells disappeared with a half-time of about three days. A few surviving cells, estimated as less than $5 \%$ of the number originally present in the circulation, could still be detected 10 days after the injection of anti-D.

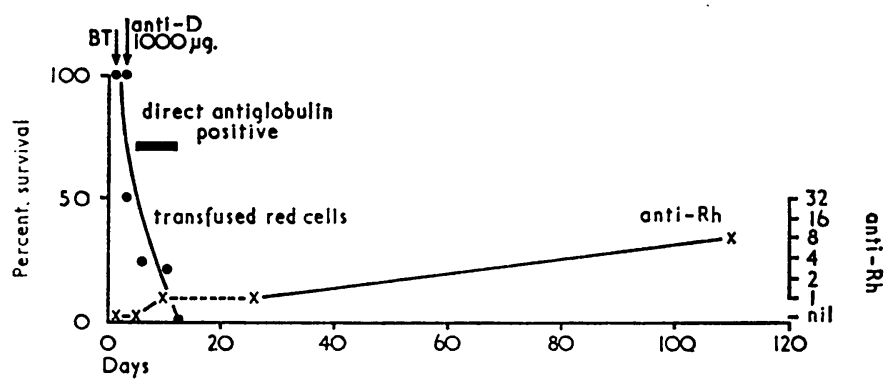

Fig. 2.-Case 2. Survival of transfused Rh-positive red cells and changes in anti-Rh titre. (BT $=$ blood transfusion.)

Forty-eight hours after the injection of anti-D the patient's direct antiglobulin test became positive and anti-D could be detected in the serum by the indirect antiglobulin test, but only when the sensitivity of this test was increased by incubating 1,000 volumes of the patient's plasma with 1 volume of red cells (see Mollison and Hughes-Jones, 1967). The indirect antiglobulin test was still very weakly positive 10 days after the injection of anti-D, and a trace of anti-D could still be detected in the patient's serum 24 days after the anti-D had been given.

A further blood sample was taken from the patient on 18 October, 107 days after the anti-D was given, and this sample was tested in parallel with the sample taken on 27 July. With the standard form of the indirect antiglobulin test (20 volumes of serum incubated with 1 volume of cells) the titre on 27 July was 1 (only a trace reaction with undiluted serum), whereas the titre of the sample taken on 18 October was 8 . This was taken as unequivocal evidence that the patient had become actively immunized.

\section{Discussion}

The reason for the failure to prevent active $\mathbf{R h}$-immunization in these two cases must remain conjectural until more is known about the mode of action of passively administered anti-D.

Delay in giving the anti-D is unlikely to have affected the outcome in Case 2, since the antibody was given only 48 hours after the transfusion, and there is evidence that anti-D is effective when given as late as 72 hours after an injection of $\mathrm{Rh}-$ positive cclls (Freda et al., 1964). In Case 1 the time of entry of Rh-positive cells into the mother's circulation can only be surmised. In view of the infant's poor condition at birth it seems likely that the greater part of the haemorrhage had occurred not more than 48 hours previously (it is unlikely to have been less than 24 hours, since the haemoglobin concentration six hours after birth was 6.3 g. $/ 100 \mathrm{ml}$.). A further reason for thinking that the haemorrhage occurred mainly during labour is simply that transplacental haemorrhage occurs most commonly during this period. If no substantial transplacental haemorrhage occurred more than 24 hours before delivery then the anti- $\mathrm{D}$ was given within about four days of the event.

Evidence has accumulated that passively administered antibody inhibits primary immunization by combining with antigen and preventing it from reacting with, and stimulating, the antibody-producing lymphocytes. The critical reaction probably occurs after antigen has been phagocytosed, since a particular antibody suppresses only the corresponding antigen and not other antigens carried on the same molecule (Brody et al., 1967).

There are approximately $12,000 \mathrm{D}$ antigen sites on an $R_{1} \mathbf{r}$ cell, and the effectiveness of the administered anti-D will depend on the extent to which it is combined with these sites. In fact, it will presumably depend on the binding of anti-D to the. antigenic "particles" which remain after the Rh-positive cells have been digested by macrophages, but in the following argument it will be assumed that the number of antigenic "particles" is the same as the number of antigen sites on the intact red cell.

The extent of the reaction between $D$ and anti-D is dependent on the concentration of antibody and the average value and heterogeneity of the equilibrium constant $(K)$ of the antigenantibody reaction. These values have been estimated (HughesJones, 1967) for the two batches of anti-D given to these patients and found to be: for batch $A, K=4 \times 10^{8} \mathrm{l} . / \mathrm{mole}$, heterogeneity index (a) $=0.8$; for batch $\mathrm{B}, \mathrm{K}=1.6 \times 10^{8} \mathrm{l}$./ mole, $\mathrm{a}=0.7$. It is thus possible to calculate how much antibody should have been attached to the Rh-positive cells if the reaction had proceeded to equilibrium. This calculation was carried out with the aid of the Sips adsorption isotherm, as described by Karush (1962). In Case $154 \%$ of the injected antibody was bound and occupied $10 \%$ of the D antigen sites on the surface of the cells and in Case $264 \%$ of the antibody was bound and occupied $5 \%$ of the $\mathrm{D}$ antigen sites.

Preliminary (unpublished) observations suggest that when $1 \mathrm{ml}$. of $\mathrm{Rh}$-positive red cells is given together with as little as $75 \mu \mathrm{g}$. of anti-D, primary immunization is suppressed; it can be calculated that under these conditions only about $10 \%$ of the $\mathrm{Rh}$ antigen sites are combined with antibody. If so, it must be concluded that the chance of primary immunization depends not only on the percentage of unbound antigen sites but also on the absolute number. For example, in order to suppress primary immunization by as much as $400 \mathrm{ml}$. of $\mathrm{Rh}-$ positive red cells it may be necessary to bind $50 \%$ of the antigen sites; it can be calculated that this would require the injection of $10,000 \mu \mathrm{g}$. of anti-D (equivalent approximately to $100 \mathrm{ml}$. of an anti-D solution with an indirect antiglobulin titre of 5,000). If such an amount is tried in the future, it would be wise to give the anti-D in divided doses; thus, $3,000 \mu \mathrm{g}$. might be given initially and further doses be given at 24-hour intervals provided that no untoward signs, due to rapid red cell destruction, developed.

In the present cases the rather prompt development of anti$\mathrm{Rh}$ suggests the possibility that the passively administered antibody augmented primary immunization and that the use of relatively small doses of IgG antibody may thus be harmful (cf. Pollack, 1967).

\section{Summary}

Two cases are reported in which Rh-negative patients who had not previously been exposed to the $R h$ antigen received respectively $60 \mathrm{ml}$. and $400 \mathrm{ml}$. of $\mathrm{Rh}$-positive red cells, in the first case by transplacental haemorrhage and in the second by transfusion. Gammaglobulin containing $500 \mu \mathrm{g}$. of anti-D (in the first case) and $1,000 \mu \mathrm{g}$. of anti-D (in the second case) was given, but failed to prevent primary immunization.

We thank Mr. J. K. Morrison for allowing us to investigate and treat the first patient, Dr. L. Sinclair for permission to refer to clinical notes on the infant, and Dr. A. Green, in whose laboratisry the diagnosis of transplacental haemorrhage was established. We also thank Mrs. Jane Wessely for carrying out serological tests and Miss Marie Burton and Miss Margaret Lindsay for counts of foetal red cells.

\section{REPERBNCES}

Brody, N. I., Walker, J. G., and Siskind, G. W. (1967). 7. exp. Med. Clarke, C. A., et al. (1966). Brit. med. \%., $2,907$.

Freda, V. J., Gorman, J. G., and Pollack, W. (1964). Transtusinn (Philad.), 4, 26.

Hughes-Jones, N. C. (1967). Immunology, 12, 565.

Karush, F. (1962). In Advances in Immunology, vol. 2, edited by $\mathrm{H}$ Taliaferro and J. H. Humphrey. New York.

Mollison, P. L., and Hughes-Jones, N. C. (1967). Immunology, 12. 63. Pollack, W. (1967). Communication to Amer. Soc. Hematol., Toronto. 